\title{
Economic democracy and business governance in Meade's works
}

\author{
Gaetano Cuomo a* \\ a Università di Napoli Federico II, Department of Law, Napoli, Italy \\ *Corresponding author's e-mail: gaetano.cuomo@unina.it
}

\author{
H I G H L I G H T S: \\ 1. The paper discusses a new business firm to overcome the conflict between capital and labour. \\ 2. The Discriminating Labour-Capital Partnership, proposed by Meade, is examined in minute details. \\ 3. An unusual economic policy that rethinks the role of the State is considered. \\ 4. The weaknesses of Meade's overall project are highlighted.
}

\begin{abstract}
Article History
\section{ABSTRACT}

Received: 26-11-2014

Revised: $19-12-2014$

Accepted: 29-01-2015

Available online: 03-02-2015

The supposedly inefficient use of resources in producer cooperatives has been the object of eager debate among theorists for decades. This debate originated from the fact that Ward and Vanek, whose model had long been rated as a blueprint for the working of cooperatives, had reached the conclusion that their short-run behaviour was not Pareto-optimal. Their finding is highlighted by a downward sloping supply curve. The first solution suggested by Meade was differentiating the pay rates of workers assigned to the same jobs, in terms of fixing the incomes of new entrants at levels not exceeding the value generated by their work inputs. The

Keywords:

Finance; Inegalitarian Cooperative does solve short-term problems, but fails to remove the odds faced by

Governance;

Labour-managed firms;

Welfare. cooperatives when it comes to financing their investments and working capital. In later years, Meade proposes a new business form in order to deal with the last mentioned drawbacks. The business form concerned is the Discriminating Labour-Capital Partnership, whose microeconomic characteristics will be analysed in this paper. The issue discussed by Meade has great importance with regard to the current debate on social welfare because it provides a comprehensive reform of the fiscal and social policy by introducing, inter alia, a generalized and

JEL Classification: unconditional social dividend. The critical analysis of his works shows some weaknesses.
\end{abstract}

J54; G34; G32; I30.

(C) 2015 The Authors. This is an open access article under the terms of the Creative Commons Attribution License 4.0, which allows use, distribution and reproduction in any medium, provided the original work is properly cited.

\subsection{Introduction}

The supposedly inefficient use of resources in producer cooperatives has been the object of eager debate among theorists for decades. This debate originated from the fact that Ward and Vanek ${ }^{1}$, whose model had long been rated as a blueprint for the working of cooperatives, had reached the conclusion that these firms were unable to allocate resources efficiently in the short run or, in rigorous terms, that their short-run behaviour was not Pareto-optimal. Their finding is highlighted by a downward-sloping supply curve. The solution suggested by Meade (1972a) was differentiating the pay rates of workers assigned to the same jobs, in terms of fixing the incomes of new entrants at levels not exceeding the value generated by their work inputs. Providing evidence that this simple rule would make it convenient for a cooperative to increase both its output and, hence, its demand for labour in proportion to rises in

${ }^{1}$ The publication of a paper by Benjamin Ward in 1958 (Ward 1958) gave rise to a new branch of economic theory which was further developed in a full-length study by Vanek (1970). 
the market prices of its products, Meade argued that such a strategy would effectively reverse the inefficient allocation of resources in cooperatives.

On closer analysis, though, the Inegalitarian Cooperative that Meade devised as an alternative option to Ward and Vanek's egalitarian firm model does solve short-term problems, but not the difficulties faced by cooperatives when it comes to financing their investments and working capital. All else equal, as a result of the truncated time horizons of the partners, a cooperative is likely to make lesser investments than its capitalistic twin company. In other words, those partners who are about to leave the firm will vote against the internal financing of projects entailing cuts on dividends unless the relevant loss is offset by material prospects of more substantial returns over the period of time they will be staying on. If there are enough exiting workers to influence the decisions of the collective, any investment project of this type is likely to be cancelled ${ }^{2}$. For this reason, Meade's inegalitarian cooperative is neither capable of solving the above-mentioned dynamic problems associated with the transmission of capital benefits from one generation of workers to the other, nor of appreciably improving the firm's external capital attraction potential.

The paper in which Meade introduced his inegalitarian cooperative model includes an outline of the business form he fine-tuned in later years in order to deal with the last mentioned drawbacks. The business form concerned is the Discriminating Labour-Capital Partnership, whose microeconomic characteristics will be analysed in this paper in order to show that Meade rated it as a natural evolution of the inegalitarian cooperative intended to serve the abovementioned purposes.

At the same time, Meade realizes that the new kind of business enterprise he proposes may be the instrument for a comprehensive economic and social reform if its introduction is supported by appropriate macroeconomic measures. This leads to the provision of a universal and unconditional social dividend not funded by traditional measures of fiscal policy, but mainly by the proceeds of the capital accumulated by the State in the form of non-controlling interests in private companies. Essentially Meade suggests a heavy State intervention in the economy implemented with an original conversion of the public debt into public credit. He also proposes a program aimed at spreading the wealth through the promotion of savings, to be implemented with a major tax reform based on the taxation of income used for consumption in place of the customary earned income.

In the literature, the hypothesis of a wide use of the social dividend is often proposed, but in most cases, this measure is considerate not feasible for its adverse effects on the public finance. Thus the debate has come to a stalemate: on the one hand, there are those who are strongly in favour of such intervention, enlarged in favour of a significant part of the population, but without proposing viable measures to cover financial burden on the State, and on the other, those who believe that this measure is not practicable on a large scale.

Meade's suggestion offers the advantage of providing a form of coverage of social dividend that does not worsen budget deficit, with even positive side effects in case of stagnation. So there are reasons to consider it the subject of a research plan, of which this work is part, to examine in detail the contribution of the author in the fields of fiscal and social policy and economic democracy, both in micro- and macroeconomic aspects.

This paper considers the first part of Meade's proposal, which is essentially microeconomic in nature and tends to overcome the difficulties in the relationship between labor and capital. The economic facts show the existence of a dominant type of capitalist enterprise that meets structural difficulties in the management of labour. On the other hand, the cooperative firms, namely enterprises controlled by workers, see their spread hampered by financial problems or, to say the same thing with other words, by the difficulties of managing capital. Again, in literature there is a dialogue of the deaf between the proponents of traditional capitalist and cooperative enterprise, without any possibility of rapprochement. Meade tries to solve these problems by proposing an interesting form of enterprise in which labour and capital can collaborate. In this paper a critical analysis of his proposal is produced.

The organization of this paper is as follows. Section 2 offers a description of the main aspects of this new type of partnership. Section 3 discusses its effects on income distribution, labour demand and investment. Section 4 examines issues associated with risk assumption on the part of the workers, whereas Section 5 analyses some of the effects of the particular labour-capital relation typifying this firm. Section 6 includes collateral fiscal and social policy provisions, whereas Section 7 states the conclusions.

\subsection{The discriminating labour-capital partnership}

In a book which was first published in 1989 (Meade 1989) and then revised and re-printed (Meade 1993), Meade made a number of microeconomic recommendations designed to induce modern Western economies to introduce

2 Major approaches to the underinvestment issue include: Pejovich 1969; Furubotn \& Pejovich 1970a, 1970b, 1972, 1973; Furubotn 1971, 1974, 1976, 1978, 1980a, 1980b. 
mechanisms to foster full employment. Meade's work included suggestions for the enforcement of macroeconomic measures apt to improve income distribution and support the effective implementation of the proposed institutional amendments.

The main tool suggested by Meade is the Discriminating Labour-Capital Partnership (from here on, in short, DLCP), which is defined as a co-operative in which workers and capitalists negotiate an agreement which fixes the amounts of their respective labour and capital inputs and the firm's profit appropriation criterion and provides for the issuance of two different categories of shares, namely labour shares and capital shares for allotment to the former and the latter respectively. As these two types of shares bear the same dividend, their respective proportions in the aggregate issue reflect the profit sharing scheme fixed for the two categories of shareholders. Like ordinary shares, capital shares are freely transferable and can consequently be traded in any stock exchange. In addition to this, they entitle the holders to vote at meetings, to be paid dividends thereon and to cash a share of the liquidated capital upon the dissolution of the partnership. Labour shares entitle their holders to vote at meetings and to cash the relevant dividends, but are registered in the name of the worker to whom they are assigned and are not transferable. In the event the worker concerned should leave the firm for causes independent of his will and unrelated to his conduct, for instance in situations of overstaffing, the rights attaching to these shares continue to inure to his benefit provided he declares that in case of need he is willing to resume discharging the tasks for which he was hired. On the contrary, labour shares are cancelled if a worker exits the firm voluntarily, retires from his job or is fired for misconduct.

In a Labour-Capital Partnership the relations between the stakeholders are exclusively founded on mutual consent and can take a variety of different forms. By way of example, wage labour is fully compatible with this type of firm and may be employed either because some workers are reluctant to take on entrepreneurial risks or because the firms deem it convenient to enter into contracts of employment. The credit investment financing option also is fully compatible if the partners resolve that enlarging the shareholder base is not in the interests of capital providers or the firm as a whole. As a result, the stakeholders of a single firm may simultaneously include capital shareholders, debt-holding partners, labour shareholders and wage earners. In addition to these, there may be multiple-status partners, since a worker may draw part of his income from a fixed wage or salary and the remaining part from the dividends on his labour shares.

Coming to the governance rules of the DLCP, Meade suggests having the firm managed by a board of directors composed of representatives of capitalists and workers in equal proportions. "The capitalist shareholders and the labour shareholders each separately elect the same number of full-time members for a board of directors. These directors appoint by agreement an additional chairman with a casting vote who thus acts as an 'arbitrator' in the case of a conflict between the two sets of directors" (Meade 1993, p. 110). As the board of directors appoints a managing director empowered to make all operational decisions, only the most important resolutions will be submitted to the board for approval.

In all probability, this short outline has made it sufficiently clear that the DLCP is a compound of the inegalitarian cooperative and the ordinary company (which is inegalitarian by its very nature) and can be defined as a cooperative which remunerates capitalists and workers based on a pre-fixed number of shares and in which no factor can be said to be hired by the other ${ }^{3}$.

Irrespective of the formal regulations governing board proceedings, in the DLCP conflicts of interests opposing capital to labour are mainly solved through a number of automatic mechanisms, first and foremost the principle that both categories of shares bear the same dividend. As a result, any resolutions designed to increase the surplus of the firm will be supported by both these interest groups. Additionally, the differential remuneration principle allows creating a consensus concerning such strategic choices as increasing investments or the firm's personnel. In either case, the relevant resolution will only be passed if the expected surplus exceeds the amount of the dividends to be paid on the newly-issued capital shares in the former case and on the newly-issued labour shares in the latter case. Thanks to this criterion, it is possible to step up the dividends paid to the senior shareholders of either category. In point of fact, this criterion is only applicable if the new entrants, despite making capital or labour contributions in the same amount as those paid by senior shareholders, are allotted a smaller number of shares than those held by these, i.e. if the remuneration of the new entrants falls short of that allotted to senior shareholders. Consequently, it is evident that for new entrants to reckon this operation as expedient they will have to be offered an income at least level with that of alternative opportunities available in the market.

On closer analysis, the founding principle of the capitalistic enterprise is the differential remuneration criterion. In capitalistic companies, new investments to be financed through additional share issues or new hires will only be made if the expected returns on the operation concerned exceed its cost, i.e. provided the existing shareholders rate it as

\footnotetext{
3 "There is no reason why one should not go the whole hog in participation and profit-sharing and apply the same principle both to those who supply the capital and those who supply the labour. Such a set-up would be a combination of an Inegalitarian Joint-Stock firm (as far as the supply of capital was concerned) and an Inegalitarian Co-operative (as far as the supply of labour was concerned)", Meade (1972a), p. 425.
} 
profitable. The importance that this principle carries for the growth of the firm concerned can only be correctly appraised if we compare it with models that do not apply this criterion, for instance with the Ward-Vanek cooperative which apportions the surplus between senior partners and new entrants on strictly egalitarian terms.

As far as capital is concerned, in ordinary companies the 'equal pay for equal job' rule that it strictly observed in the Ward-Vanek model would be matched by the 'equal return for equal capital contribution' principle without regard to the time when the contribution was made. As is well known, companies adopt a different principle: the founding shareholders subscribe for shares at par, whereas new entrants joining the enterprise on the occasion of capital increases pay the par value of the shares plus an extra charge computed by senior shareholders by reference to the market value of the enterprise. Ultimately, in exchange for a capital contribution in the same amount as that previously disbursed by an existing shareholder a new entrant will obtain a smaller number of shares.

\subsection{Effects of the DLCP on income distribution}

Unlike capital shares, labour shares are registered in the name of the holder. As mentioned above, Meade specifies that they are cancelled upon the retirement or resignation of the worker concerned (Rule of Cancellation). Accordingly, let us assume that a worker should join a DLCP under a variable income agreement envisaging the allotment of labour shares which are expected to carry shareholder returns on a par with the average wage rate. If the income of a retiring or quitting worker is still level with or short of this rate, to replace the partner the firm will only have to cancel the labour shares in his name and issue an equal number of shares for allotment to the new entrant. Conversely, if a positive trend in the firm's operations has resulted in raising the worker's earnings to a level above the average wage rate, the replacement process will be rather more complex. In such a case, the labour shares of the exiting partner must be virtually split into two groups: those remunerating the partner for his work input and the remaining ones, which entitle him to a pro-rata portion of the firm's profit. Although the shares of the exiting party are cancelled in their entirety, the new entrant will only be entitled to newly-issued shares remunerating him for his labour input. The balance of the returns that used to accrue to the existing partners and those accruing to the new entrant will go to step up the dividends on the outstanding labour and capital shares. As a result, all the shares will bear a higher dividend, but labour shares will decrease in number while the aggregate number of capital shares will remain constant. In due time, the gains that would have accrued on the cancelled labour shares will also go to increase the returns on the capital shares. In such a way, every turnover of partners will result in a different income distribution pattern comparable to that of systems entirely formed of capitalistic enterprises: profits will be gathered into the hands of capital shareholders and the rate of return on the labour shares will tend to decline to the wage rate prevailing in the market. The pace at which income is redistributed in favour of capital shareholders accelerates in direct proportion to the capitalist's initial equity stake in the (arguably capital-intensive) firm and to the staff turnover rate.

These reflections highlight a major difference between the insider-outsider relations prevailing in Meade's DLCP and those typifying entrepreneurial firms: whereas the workers of the former deem it in their interests to keep the market wage rate low for the sake of increasing their rates of return, senior employees in the latter tend to pursue the opposite aim since the low wages paid to new entrants detract from the legitimacy of the wage increases accruing to them ${ }^{4}$. Due to this characteristic, the potential of a DLCP for increasing employment and providing an impulse to the economy is superior to that of the capitalistic enterprise. The other side of the coin is that in a an economic system formed of DLCPs and entrepreneurial firms the efforts of the former to keep wages low may produce redistributive effects to the detriment of the workers.

Quite obviously, the problem of guaranteeing permanent earnings to retiring workers would not be less urgent in an economy with DLCPs. Not unlike what happens in capitalistic enterprises, also in a Labour-Capital Partnerships the wages and profits of workers would be subject to social security withholdings under a pension scheme. Consequently, the resulting pension payments would be commensurate with the sum of the partner's income from work and the total profit cashed. At any rate, regardless of whether or not workers are guaranteed permanent pension payments, the cancellation of their labour shares is and remains a matter for debate.

The fact that the labour shares remunerating a partner for his work are cancelled upon his exit from the firm is barely objectionable, given the need to issue an equal number of shares for allotment to the new entrant. The questionable point is the shareholder returns that the partner used to earn in periods when the firm was operating at a profit. Is there really no option to the cancellation of the labour shares entitling workers to a part of the firm's profit? As mentioned above, upon the cancellation of the shares the relevant returns are re-allocated from the exiting partner to the capital shareholders and the working partners continuing their work in the firm. In point of fact, it is far from easy to decide if this arrangement can be described as fair. Those holding that the income from a firm's operations

${ }^{4}$ For an analysis of this point in capitalistic enterprises, see Lindbeck \& Snower 1986. For a more comprehensive approach, refer to Hahn \& Solow 1995. 
should accrue to those who are directly involved in the production process tend to deny that any other parties my lay in a claim on such income. At the other end of the spectrum are those who maintain that the work inputs of any type and amount that boost the firm's earning potential will also raise its market value and should therefore be remunerated separately. In other words, on the assumption that higher returns today will help boost the firm's future earnings, they maintain that each exiting worker should be entitled to the capitalised value of the profits he would have cashed if he had stayed ${ }^{5}$.

Meade does suggest options to the cancellation of the profit-related labour shares, but he also emphasises that any alternative solutions would be difficult to implement. First and foremost, the shares might not be cancelled if the excess amount paid out to the exiting partner were classed as his capital return and used to issue bonus capital shares for allotment to him (Rule of Retention). Thanks to the conversion of part of his labour shares into capital shares, a retiring worker would continue to cash the higher income that would have accrued to him thanks to the rise in the firm's profit. In this way, the aggregate number of shares would remain constant, but the proportions of the two categories of shares would be altered. More specifically, part of the surplus would be redistributed in favour of capital, but this process would be implemented by increasing the number of capital return earners, rather than allotting the whole surplus to existing capital shareholders.

The second option proposed by Meade is to redistribute the exiting partner's additional earnings by apportioning them among the other workers of the firm, to the exclusion of capital shareholders (Rule of Redistribution). This means that the profit which is part of the income of an existing worker would be apportioned among those who stay thanks to the issuance of new labour shares in their favour. Conversely, the new entrant would only receive a dividend in the amount of the average wage rate of labour. As a result, a turnover of staff would not alter the initial proportions of the surplus respectively allotted to labour and capital shares.

On the face of it, the Retention and Redistribution rules would seem to be the fairer solutions, but Meade makes it clear that both of them entail adverse effects that make them inapplicable. In periods when the firm operates at a profit and expects its positive performance to be stable and lasting, the application of the Rule of Redistribution may impede rises in employment since the younger partners will oppose new hires in an attempt to avoid enlarging the labour shareholder base entitled to the redistribution of the income from the shares of the retiring workers. This opposition will escalate in direct proportion to the aggregate amount of the profits that the exiting partners used to receive.

Conversely, notwithstanding prospects of a lastingly positive performance the conversion of part of the firm's labour shares into capital shares for allotment to exiting workers (Rule of Retention) will not slow down the growth in employment since younger partners would not have any incentive to oppose new hires. Indeed, the senior partners leaving the firm would retain title to their shareholder returns and, consequently, no resources would be available for distribution to the workers staying with the firm. However, if the firm's performance should turn out to be volatile, the application of the Rule of Retention would put capital shareholders at a disadvantage and ultimately discourage fresh venture capital investments.

\subsection{The scant risk propensity of workers and profit distribution - two major issues}

In the DLCP, entrepreneurial risks are borne both by capital shareholders and by workers, but while the former can diversify and, hence, reduce risks by participating in a variety of activities, the latter are dependent on the operating results of their firm as a matter of course. This point is of far-reaching importance since the acknowledgement of the DLCP's potential for furthering worker involvement in operational decision-making is largely dependent on it. The only way to balance off these risks at least in part is favouring an equitable distribution of wealth primarily through the allotment of capital shares to workers. As argued by Meade, this finding has implications for the State, which is called upon to ease the access of all citizens to the direct or indirect ownership of portions of the national wealth through the stepwise enforcement of far-reaching fiscal reforms.

\footnotetext{
${ }^{5}$ The former stance is clearly, though not convincingly, endorsed by Ellerman $(1982,1986,1992)$, who argues that profit is the result of a social process and should accrue to the party organising the operations of the factors. i.e. that profit is generated by the interaction between factors and does not inure to the benefit of the owner as a matter of course. In Ellerman's opinion, it is for this reason that profit generation and title to cash such profit should arise simultaneously and that the title concerned should accrue to the party performing the entrepreneurial function - with the major consequence that no one is entitled to claim title, today, in profits that are assumed to be generated in future. One possible objection is that the nature of profit, as the result of the interaction between factors, rules out the claim that the material generation of income and the title to appropriate it should arise simultaneously. There is a possibility that viable entrepreneurial choices made today will generate positive effects on profit generation only in the long run, and this means that the profit-generating social relationship may commence at a point in time prior to the time-span during which the profits concerned are actually earned and that any party that helped spark off this process should have title to part of the relevant benefits regardless of whether he will or will not be a member at the time such profits start accruing - provided always the measures are favourably received in markets. This seems to be the opinion of Sertel $(1982,1987)$ and Fehr $(1993 a, 1993 b)$, according to whom a job carrying a variable pay rate is worth an amount commensurate with its expected future cash flows and that such job should be negotiable for this reason. Accordingly, if exiting working partners were authorised to transfer their status to third parties, they would be able to recover the present value of the prospective future returns they are waiving. This hypothesis is opposed by Meade (1993, p. 129).
} 
On closer analysis, the labour shareholders of a DLCP run lesser risks than the employees of capitalistic companies since they cannot be dismissed in situations of overstaffing ${ }^{6}$. More precisely, on entering the firm, with the consent of the management, labour shareholders are in a position to opt for a larger or smaller fixed income proportion, depending on whether they prefer to be principally at risk of lay-off or of shortfalls in earnings. By way of exampleand considering extreme cases only - the highest risks of dismissal are run by fixed-pay workers, whereas the highest risks of shortfalls in income are faced by labour-shareholders who are exclusively dividend earners. Let us assume that jobs can be ranked in increasing order of productivity. In such a case, upon a downswing in the firm's operations it is workers assigned to less productive jobs that run the severest risks of dismissal and it is these that will strive to de-escalate such risks by opting for variable earnings and shift them onto the fixed-pay workers assigned to jobs with slightly higher productivity levels. This process will run on if the latter try to protect themselves by opting for variable incomes. Eventually, to ward off risks of demand-deficient unemployment most of the workers will opt for the variable incomes associated with labour shares.

According to Meade, therefore, workers prefer to accept volatile incomes rather than run the risk of losing their jobs. On the one hand, this may lead to an increase in variable-income jobs; on the other, there would be adverse repercussions for capital shareholders - a point which Meade failed to discuss. If the process should actually run on in the way just described, the firm would be prevented from using dismissals as an ex post selection mechanism, that is to say it would not be able to adopt the practice that capitalistic companies are held to put in place in or der to get rid of workers whose work inputs, though deficient, are above the threshold that would justify ousting them.

In any case, the suppression or reduction of hired labour positions might have a perverse impact on labour productivity since the firm would not be in a position to get rid of less efficient workers (in cases other than serious misconduct or glaringly insufficient work inputs). The only incentive system left open to them would be a sophisticated mechanism comparable to the one adopted by fairly more structured capitalistic enterprises, i.e. promoting their most efficient workers to positions that will entitle them to additional labour shares. As far as less productive workers are concerned, in a worst-case scenario they would be barred from future pay increases. This scenario is the direct consequence of the fact that the starting income of a worker in Meade's model depends on the dividend that is carried by the shares he subscribed for on entry and is consequently unrelated to the effort he will be putting in his work (provided always such effort is measurable). This means that personnel management in a DLCP would be, on average, more complex and costly than it is in traditional enterprises.

From the finding that workers prioritise stable jobs over stable incomes, it follows that one of the most sensitive problems a DLCP is called upon to deal with is fixing the proportions of the surplus that will have to be allotted to the two different categories of shareholders. In the opinion of Meade, DLCPs and their capitalistic 'twins' must necessarily adopt different income distribution systems. The founders of a DLCP should reckon with the fact that in this type of firm - unlike entrepreneurial firms - both capital shareholders and workers come in for direct entrepreneurial risks. Additionally, if changes in the labour market were to alter the value of the partners' work inputs, the firm should be in a position to adjust the partnership interests accordingly. Consequently, if there are signs that some workers may be planning to move to other firms - in which case the capital shareholders would face greater cuts on their earnings than those associated with a redistribution of the net profit - the firm should consider allotting a greater share of its surplus to labour.

All the same, even though the amounts of the partnership interests were fixed via consensus-carried resolutions, this would not solve the problem of devising a fair appropriation of the surplus. For instance, the practice of retaining earnings for future needs instead of distributing them penalises labour shareholders while leaving capital shareholders unscathed. The solution suggested by Meade in these cases is issuing capital shares and allotting them to all the partners, both capital and labour shareholders. An alternative solution is issuing shares for allotment to capital shareholders only and avoiding to cut the earnings of the workers by continuing to pay out dividends on the labour shares. It is much more difficult to work out an effective solution for cases where the firm is engaged in major restructuring processes requiring considerable investments and deferred cash flows. The more or less lasting cuts on dividends made necessary by such a project would penalise workers about to retire, in terms that they will not benefit from the expected upswing in the firm's future performance. In such a case, workers about to retire might be compensated for the relevant loss through the issuance of a negotiated number of capital shares. Quite obviously, no shares would be allotted to workers with longer time horizons and, hence, likely to benefit from the earnings expected to flow from the relevant innovative investments.

In point of fact, Meade fails to analyse the whole range of possible cases. Profit retention is not the only problem. Indeed, a firm that hides the whole or part of its profits can be assumed to be setting aside undisclosed reserves for self-financing purposes and concealing the surplus from the workers to prevent them from claiming the payments to which they are entitled. It goes without saying that such a move would play into the hands of capital shareholders

${ }^{6}$ Labour shareholders can only be fired for misconduct (see Section 2). 
and might prove successful if these managed to exercise an undue influence on the members of the Board. On closer analysis, though, the opposite hypothesis is equally realistic. If the management should come under the influence of the labour shareholders, the firm might resolve to distribute unearned profits with the aim of favouring variable income workers at least in the short term. Indeed, in such situations the interests of the two entrepreneurial inputs present in the DLCP might indeed be antithetical. The extent to which the interests of the two inputs converge in matters of accurate profit determination depends on the workers' time horizons, specifically the horizon of the median worker ${ }^{7}$.

The shorter their time horizons, the less will the workers be concerned with the future viability of the firm and the more will they press for the correct determination and prompt distribution of possibly high profits on the assumption that any dividends not cashed today will be ultimately forfeited. At the other end of the spectrum, the main concern of capital shareholders is with maximising the value of their shares, and this is why they prioritise the prospect of cashing future earnings for a virtually indefinite period of time. In due time, both hidden profits and those which are reported in the balance sheet as retained profits enable the firm to gain strength and value - and within an efficient securities market the growth of a firm is likely to drive up the value of its capital shares. As a result, the capital shareholders are aware that the practice of underreporting profits is counterbalanced by an increase in the firm's net worth and, consequently, in the value of their holdings. These reflections point that a DLCP will have to put in place rules purposely designed to ensure the proper circulation of information on the firm's performance and the methods used to determine the results of its operations, i.e. data to which only the firm's executives are usually privy.

\subsection{Effects of the ban on dismissals}

As mentioned above, in situations of overstaffing, the redundant workers that have to be dismissed would retain title to the dividends accruing on the labour shares registered in their names. The dismissal of a worker would only cancel the fixed component of the earnings agreed with the firm upon his entry. A comparative analysis of the DLCP and entrepreneurial firms will show that the capital shareholders of the former are at a disadvantage since they forfeit the proceeds of the dividends they are in any case obliged to pay out to redundant workers. On the other hand, it is worth considering that in periods of crisis the firm is likely to record a decline in its earnings which will drive down the dividend per head to a level below the market wage rate. Unlike what happens in capitalistic enterprises, in a DLCP a crisis from labour redundancy squeezes down labour costs due to falls in profits, which means that the adverse implications for shareholders would be reduced and might even decrease to nil if the firm should not report any profits.

The situation is different when personnel redundancies are caused by technological innovations leading to the use of new machinery in place of manual workers. In such a case, although the redundant workers cease their role in the production process, the firm will have to pay them the agreed share of its profits until they go into retirement. In an attempt to minimise this problem, Meade remarks that:

a) the above-mentioned disadvantage to capital shareholders will only arise if there is no way to defer the investments concerned until the passing of time results in a natural decrease in the firm's staff;

b) the damage caused to capital shareholders is in any case restricted to the variable part of the workers' earnings;

c) the problem will not affect start-ups established to put to use technological breakthroughs;

d) traditional capitalistic enterprises also come up against stout opposition from unions when they plan to introduce technological innovations which result in considerable staff redundancies;

e) following dismissal, the workers of a DLCP would have to remain on call under forfeiture of their labour shares.

On closer analysis, none of these arguments offer effective solutions to the problem of technology-related labour redundancy. At best, Meade's remarks go to downscale the odds faced by DLCPs compared to capitalistic enterprises. Furthermore, it is worth considering that the need to pay out dividends to laid-off workers for many years running may result in an incentive to the employment of salaried workers even in DLCPs.

The ban on dismissals as analysed in this section leads to additional difficulties pointed up by Meade himself. On being dismissed, a worker who is paid both a fixed salary and dividends on his labour shares would forfeit the fixed component of his total earnings, as mentioned before. Where he should subsequently be reinstated to the job for which he used to be paid a fixed salary, it might be found that his wage rate is no longer commensurate with the market rate. In such a case, his reinstatement would necessitate the execution of a new contract of employment and the concomitant renegotiation of his salary. Moreover, given the absence of reference criteria, in a fairly large number of cases the parties engaged in the relevant renegotiation processes are likely to go to court or have the matter submitted to arbitration.

\footnotetext{
7 The median worker is the one who occupies the central position on a scale ranking workers based on the periods of time they respectively expect to stay on in the firm.
} 
There is good ground for arguing that labour disputes would escalate and become even more complex also for different reasons. On being fired, workers would have a strong incentive to have their ousting classed as redundancy dismissals and, hence, avoid having their labour shares cancelled, while firms with excess staff would probably resort to shady manoeuvres to induce the redundant workers to resign.

\subsection{Full employment, flexible labour earnings and the role of the State}

Analysing a model economy assumed to be entirely composed of DLCPs, it is found that in situations of falling demand dismissals could be avoided or reduced if all the workers were only paid the dividends accruing on their shares. Conversely, if ordinary firms in a capitalistic economy were to face reiterated falls in demand, they would not be able to deal with the situation by reducing prices appreciably since monetary wages are difficult to cut. As a result, they would face sudden shortfalls in profits and even losses and would have no way out but to cut costs by downsizing outputs and destaffing. On the contrary, in a participatory economy demand-related falls in revenue squeeze down the surplus, which in turn leads to the payment of lesser dividends on labour shares (in addition to capital shares)? As a result, labour costs fall and a firm will be able to reduce its prices and increase its sales so as to protect its workers.

This finding was highlighted in earlier studies by Weitzman, ${ }^{8}$ whose model envisages worker earnings comprising a fixed component and a variable portion in an amount determined by the firm's net operating result. Weitzman's firm model is a traditional business firm in which workers are hired and dismissed by capital holders and has no comanagement powers. The rationale behind Weitzman's proposal is ensuring that the fixed portion of a worker's remuneration will fall short of the equilibrium wage and, hence, of the marginal product of labour, because this will result in more demand for labour than is usually generated by the traditional pay system. The ultimate purpose of Weitzman's model is to generate a tendential downward movement in unemployment levels. As Weitzman's model is extensively discussed in the literature, its detailed description and a critical review of the objections raised against it fall outside the scope of this paper ${ }^{9}$. Suffice it to remark that the enthusiasm it initially aroused ${ }^{10}$ wore off in due time and that today it is generally held that, although it does generate brisker demand for labour than the traditional wage system, it is not necessarily suited to improve the response of firms to exogenous shocks (Nuti 1988; Zanella 2001).

Moreover, it has been pointed out that in a Weitzman-type participative economy workers face both the risk income volatility (which is unknown in capitalistic systems) and the risk of losing their jobs in the event of overstaffing (which in Weitzman's model is reduced, but not eradicated). Due to a measure of risk-averseness, before entering into a contract of employment most workers would probably require these risks to be balanced off by a bonus allowance of sorts. For its part, the firm having to disburse such bonuses might conclude that it is not worthwhile entering into the relevant contracts and revert to the more advantageous traditional wage system.

To clear the field of these risks, Meade suggests extending the entrepreneurial status to labour and bringing it level with capital (so that redundancy dismissals would be ruled out) and calls upon the State and social institutions to create the assumptions for diversifying the earnings of workers. Indeed, although flexible earnings minimise loss of jobs, they are not enough to guarantee full employment. In Meade's approach this aim can be attained through a differentiated remuneration system - one of the characteristics of the DLCP as mentioned above - on condition that new entrants are prepared to accept fully or partly variable earnings with a fixed component lower than their marginal product. As mentioned above, however, to ward off shortfalls in worker incomes the State should enforce effective social security provisions and, primarily, a social dividend ${ }^{11}$, i.e. an unconditioned subsidy paid to citizens in an amount dependent on the citizen's age bracket and family composition. The aims of such a social dividend include: 1) providing a basic income in the same amount to each citizen; 2) reducing risks of variable earnings associated with the possible volatility of other sources of income so as to increase risk propensity; 3 ) preventing the distortions that tend to arise when the payment of unemployment benefits and subsidies is made dependent on compliance with given prerequisites.

In Meade's opinion, the DLCP has a potential for reducing fixed labour costs and suppressing demand-deficient unemployment levels, but not for ensuring income distribution patterns that would tilt the balance in favour of workers. Additionally, he emphasises that the DLCP model requires workers to assume risks that they would not have to take in a traditional capitalistic economy. These drawbacks must be balanced out by measures apt to increase the propensity of workers to take risks. Specifically, as mentioned before, the decisive measure is redistributing wealth

\footnotetext{
${ }^{8}$ For the genesis and characteristics of this model, see Weitzman 1974, 1982, 1983, 1984, 1985a, 1985 b, 1987.

${ }^{9}$ See, inter alia, Tobin 1986; Nuti 1986a, 1986b, 1988; Wadhwani 1987; Amendola 1988; Potestio 1988.

10 See, inter alia, Blanchflower \& Oswald 1987.

11 The social dividend issue was a major interest of Meade. For its first mention see Meade (1935). For further discussions see Meade (1938, 1945, $1948,1971,1972 b, 1975,1976,1984,1990,1991,1995)$. The more extensive treatment of the subject is contained in Meade (1989, 1993).
} 
in favour of workers ${ }^{12}$ both directly, thanks to the enlargement of the capital shareholder base and easier access to the acquisition of other assets, and indirectly, by enabling the State to acquire wealth and use the resulting income to finance the payment of a social dividend to all the citizens. In capitalistic economies, differences in wealth tend to escalate with the passing of time. The ablest, most efficient or luckier members of society manage to maximise the returns on their activities and, by investing these earnings in lucrative operations, are able to hoard sizable capital resources. The rest of the population just manage to make ends meet. In such a situation, if no death duties are exacted by law or such duties are either extremely low or easily dodged, this concentration will further escalate without end. The different accumulation potentials of individuals justify both government action to redistribute incomes through the taxation system and the accumulation of wealth in the hands of the State, so that the returns on such property might be used to pay out income support allowances to the weaker members of society without eroding the earnings of the more proactive citizens.

As argued by Meade, to promote a more equitable distribution of wealth the government should launch radical reforms designed to encourage saving by making saved income tax-exempt. This goal can be achieved by substituting a tax on income used for consumption for the customary earned income tax. The taxable base would be the difference between the aggregate income earned and the net value of financial instruments or real property purchased by an individual. In addition to this, Meade suggests levying a fairly low tax-rate on private property, to raise the taxable base as far as possible by fixing a very low exemption threshold but, by the same token, to avoid obstructing the accumulation of wealth. This tax, he argues, should be levied on the value of the relevant assets as reported by the tax-payer himself in his tax return, and the State should be given a pre-emptive right to purchase such property at a price slightly above the value stated. Such a provision would both prevent tax-payers from minimising their taxable bases by understating the value of such property and further realistic and constantly updated estimates of aggregate national wealth, ${ }^{13}$ in addition to cutting tax evasion detecting and prosecuting costs. Lastly, Meade recommends levying fairly high inheritance and gift taxes on the assumption that such a policy is the only means of eating into private wealth for redistribution purposes. As a result, the average citizen might rely on four sources of income, i.e. the social dividend, gains on capital shares or other securities owned, a fixed salary or wage and dividends on labour shares.

For a flow diagram of Meade's proposal see Appendix.

\subsection{Conclusions and policy implications}

All things considered, Meade's proposal holds out prospects of far-reaching institutional and social reforms aimed to establish new private business forms in addition to those existing today, to fine-tune income distribution mechanisms and to widen the role of the State. Due to its sheer range and the distinctly innovative character of some of its measures, notwithstanding the aims stated in the very title of one of Meade's books ${ }^{14}$ it might be dismissed out of hand as utopian and impracticable. On closer analysis, though, Meade's highly ambitious goal, though not explicitly stated, is to cut at the very roots of economic and social relationships by severing the direct link between work and subsistence both for ethical reasons and for purposes of greater efficiency. Since the scant risk propensity of workers can be traced to their fear to lose their jobs and jeopardise their own and their families' survival, some personal property or a supplementary source of income would ensure minimal means of subsistence even when their incomes from work or their jobs are at risk. Accordingly, in Meade's view the State's institutional task should be providing for the basic needs of its citizens and the aim of work should be increasing the personal property of individuals and aggregate social wealth. From this, it follows that the function of social wealth is funding the policies put in place by the State to satisfy the basic needs of individuals.

Meade's overall approach can be summed up as follows. Although the DLCP model is intended to promote full employment and avert such typical drawbacks of the Ward-Vanek model as allocative inefficiency, underinvestment and underfinancing, in actual fact it exposes workers to risks of income volatility. According to Meade, this problem can be addressed by introducing a subsidy to be paid out to all citizens regardless of their financial conditions. There can be little doubt that such an all-comprehensive citizen support program would impose a heavy burden on the government budget: in the event it were funded through the general tax system it would undermine the viability of the entire economy, squeeze labour supply and interfere with the development of entrepreneurial skills. As a result, the State, like any private organisation, has to supplement its tax revenues by accumulating income-generating resources. In Meade's approach, the function of the assets pooled under the control of the State is to surrogate the role of private individuals: first and foremost, it is intended to balance out the inability or scant propensity of many citizens to see to this task; secondly, provided it is increased in periods of declining savings and vice versa, it may

\footnotetext{
${ }^{12}$ Concerning the claim that risk aversion in workers is caused by lack of resources, see, also, Cugno \& Ferrero 1991 and Bowles \& Gintis 1994.

${ }^{13}$ Such an estimate would have a positive effect on the accurate levying of other taxes such as death duties and gift taxes, and would prove useful for other economic policy purposes.

14 The island of Agathotopia, 'a Good Place to Live in', is contrasted by Meade with the island of Utopia, 'a Perfect Place to live in'. He reports that during his 'journey' he did visit the former, but was never able to find the latter (Meade 1989, p. 7 in the Italian edition).
} 
perform counter-cyclical functions. ${ }^{15}$ And as these resources make up a considerable portion of a nation's overall social wealth, they must be raised by degrees in order to avert fiscal sustainability problems. In any case, it will necessitate a reform of the taxation system, in terms that tax rates will have to be increased at least at the initial step of the long-drawn out transitional period leading up to the full implementation of this new social policy. The very functions of taxation will have to change, since its primary goal would be encouraging private saving and furthering the formation of small family estates. This is the aim underlying the replacement of earned income taxes with expenditure taxes and the levying of substantial death duties upon the passage of large estates from one generation to the other (Meade 1993, p. 151).

Meade's model includes two distinct groups of policy proposals: measures to support the introduction of DLCPs and macro-economic measures such as tax and welfare policies. In all probability, Meade's plan was to combine a microeconomic mechanism designed to ensure full employment with a set of measures increasing government protection on the assumption that the latter group of policies might result in neo-classical, i.e. high-wage unemployment. Indeed, besides raising the citizens' propensity to take risks, a subsidy on an adequate scale might generate perverse effects, for instance reduce labour supply and trigger an increase of the equilibrium wage rate. The variable worker incomes envisaged by the DLCP model are designed to help solve this problem in that they reduce the functions that wages perform in capitalistic enterprises. However, inasmuch as it is true that this was Meade's real goal, it is fair to say that nothing contained in his model goes to avert the risk that even a system of DLCPs will experience falls in labour supply.

Additional weak points of Meade's new business form induce us to raise serious doubts concerning its potential for achieving the functions assigned to it by its author. The governance system of his model firm is barely satisfactory. Meade suggests that capital and labour shareholders should have the same number of representatives serving on the Board irrespective of the economic weight of the two groups. The Board members would subsequently appoint a chairman acting as arbitrator in cases of conflict. Due to the considerable powers vested in the Board, the chairman would often be acting as a sole decision-maker and this may in turn have serious implications. Additionally, given that each factor is represented by an equal number of directors, capital shareholders or workers, depending on the factor outweighing the other from time to time, might perceive the DLCP as uncongenial and resolve to establish a traditional business enterprise or a cooperative.

Thanks to the participative remuneration system, none of the workers can be dismissed in situations of labour redundancy. This characteristic, which is perfectly consistent with the very nature of the DLPC, interferes with investments in labour-saving plant which despite Meade's efforts to understate the problem might ultimately slow down overall technological progress.

Overall, Meade's approach is designed to underline those plus points of DLCPs that might result in an incentive for workers to establish them, but not the reasons that should induce capital owners to opt for the generalised adoption of this business form. In all probability, although capitalists are probably not indifferent to prospects of greater macroeconomic efficiency and a potential for ensuring full employment (Zanella 2001), it is doubtful whether these plus points would be enough to offset the loss of their power positions in firms. Accordingly, whereas the fiscal and social policy suggested by Meade might help make workers more risk-prone, it is highly likely that the implementation of this new business form would be stoutly opposed by capital owners.

The full implementation of the reforms proposed by Meade takes many years and must necessarily be gradual. Regarding the microeconomic measures, examined in this work, at first they can be introduced, experimentally, only in part. On the side of cooperative enterprises, in the presence of widespread financing difficulties, law should provide the opportunity to admit financing partners with power commensurate with the capital contributed, without significant reduction of workers' sovereignty. In the traditional capitalist enterprises, worker participation not only in company profit, but also in the current management of the firm should be strongly encouraged by the State.

\section{References}

Amendola, A., 1988. Occupazione, investimenti e salario: gli effetti microeconomici della 'profit sharing'. In Jossa B (ed.), Autogestione, cooperazione e partecipazione agli utili, (pp. 39-75). Bologna, Italy: Il Mulino.

Blanchflower D.G., Oswald A.J., 1987. Profit Sharing. Can it Work?. Oxford Economic Papers, 39: 1-19.

Bowles S., Gintis H., 1994. Credit Market Imperfections and the Incidence of Worker-Owned Firms. Metroeconomica, 45: 209-223.

Cugno F., Ferrero M., 1991. Il problema degli incentivi al lavoro nella produzione cooperativa. In Zamagni S, (ed.), Imprese e mercati. Torino, Italy: Utet.

${ }_{15}$ Meade 1993, p 161. This argument is spelt out in even bolder letters in Meade 1989, pp. 91-92 of the Italian edition. 
Ellerman D.P., 1982. Economics, Accounting, and Property Theory. Lexington, MA: D. H. Heat.

Ellerman D.P., 1986. Horizon Problems and Property Rights in Labour Managed Firms. Journal of Comparative Economics, 10: 62-78.

Ellerman D.P., 1992. Property and Contract in Economics. Oxford, UK: Basil Blackwell

Fehr E., 1993a. The Labour-Capital Partnership: Reconciling Insider Power with Full Employment. In Atkinson A. B. (ed.), Alternatives to Capitalism: the Economics of Partnership. London, UK: Macmillan.

Fehr E., 1993b. The simple analytics of a membership market in a labor-managed economy. In Bowles, S., Gintis, H., Gustafsson B. (eds.), Markets and democracy: participation, accountability and efficiency. Cambridge, England: Cambridge University Press.

Furubotn E.G., 1971. Toward a Dynamic Model of the Yugoslav Firm. The Canadian Journal of Economics, 4, $182-197$.

Furubotn E.G., 1974. Bank Credit and Labor-managed Firms - the Yugoslav Case, in Furubotn, E.G. \& Pejovich, S. (eds.), The economics of property rights, Cambridge, MA: Ballinger.

Furubotn E.G., 1976. The Long-run Analysis of the Labor-managed Firm: An Alternative Interpretation. The American Economic Review, 66, 104-123.

Furubotn E.G., 1978. The Long-run Analysis of the Labor-managed Firm: Reply. The American Economic Review, 68, 706-709.

Furubotn E.G., 1980a. The Socialist Labor-managed Firm and Bank-financed Investment: Some Theoretical Issues. Journal of Comparative Economics, 4, 184-191.

Furubotn E.G., 1980b. Bank Credit and The Labor-managed Firm: Reply. The American Economic Review, 70, 800804.

Furubotn E.G., Pejovich S., 1970a. Tax Policy and Investment Decisions of the Yugoslav Firm. National Tax Journal, 23, 335-348.

Furubotn E.G., Pejovich S. (1970b). Property Rights and the Behaviour of the Firm in a Socialist State. The Example of Yugoslavia. Zeitschrift fur Nationalokonomie, 30, 431-454.

Furubotn E.G., Pejovich S., 1972. Property Rights and Economic Theory: a Survey of Recent Literature. Journal of Economic Literature, 10, 1137-1162.

Furubotn E.G., Pejovich S., 1973. Property Rights, Economic Decentralization and the Evolution of the Yugoslav Firm, 1965-72. Journal of Law and Economics, 16, 275-302.

Hahn F.H., Solow R., 1995. A Critical Essay on Modern Macroeconomic Theory. Oxford, UK: Blackwell.

Lindbeck A., Snower D.J., 1986. Wage Setting, Unemployment and Insider-Outsider Relations. The American Economic Review, 76: 235-239.

Meade J.E., 1935. Outline of an Economic Policy for a Labour Government. In Howson S. (ed.), The Collected Papers of James Meade. Volume I: Employment and Inflation, London, UK: Unwin Hyman Ltd, 1988.

Meade J.E., 1938. An Introduction to Economic Analysis and Policy. Oxford, UK: Oxford University Press.

Meade J.E., 1945. Mr. Lerner on 'The Economics of Control'. The Economic Journal, 55: 47-69.

Meade J.E., 1948. Planning and the Price Mechanism. The Liberal-Socialist Solution. London, UK: George Allen \& Unwin.

Meade J.E., 1971. The Controlled Economy. London, UK: George Allen \& Unwin.

Meade J.E., 1972a. The Theory of Labour-managed Firms and Profit Sharing. The Economic Journal, 82, $402-428$.

Meade J.E., 1972b. Poverty in the Welfare State. Oxford Economic Papers, 24: 289-326.

Meade J.E., 1975. The Intelligent Radical's Guide to Economic Policy: The Mixed Economy. London, UK: George Allen \& Unwin.

Meade J.E., 1976. The Just Economy. London, UK: George Allen \& Unwin.

Meade J.E., 1984. Full Employment, New Technologies and the Distribution of Income. Journal of Social Policy, 13: 129-146.

Meade J.E., 1989. Agathotopia. The Economics of Partnership, Aberdeen, UK: Aberdeen University Press (Italian edition: Agathotopia. L'economia della Partnership. Milano, Italy: Feltrinelli, 1989).

Meade J.E., 1990. Can we learn a 'Third Way' from the Agathotopians?. The Royal Bank of Scotland Review, n. 167: 1528.

Meade J.E., 1991. The Building of the New Europe: National Diversity versus Continental Uniformity. Edingburgh, UK: The David Hume Institute.

Meade J.E., 1993. Liberty, Equality and Efficiency. Apologia pro Agathotopia Mea, Houndmills, UK: Palgrave Macmillan.

Meade J.E., 1995. Full Employment Regained? An Agathotopian dream. Cambridge, UK: Department of Applied Economics, University of Cambridge.

Nuti D.M., 1986a. L'economia della compartecipazione: critiche al modello di Weitzman. Politica ed Economia, n. 1: 53-64.

Nuti D.M., 1986b. Partecipazione e pieno impiego. Controreplica. Politica ed Economia, n. 4: 7-8.

Nuti D.M., 1988. Codeterminazione, partecipazione agli utili e cooperazione. In Jossa B. (ed.), Autogestione, cooperazione e partecipazione agli utili, (pp. 159-173). Bologna, Italy: Il Mulino.

Pejovich S., 1969. The Firm, Monetary Policy and Property Rights in a Planned Economy. Western Economic Journal, 7, 193-200. 
Potestio P., 1988. Ambito di rilevanza e realismo della proposta di Weitzman di economia partecipativa. In Jossa B (ed.), Autogestione, cooperazione e partecipazione agli utili, (pp. 17-37). Bologna, Italy: Il Mulino.

Sertel M.R., 1982. Workers and Incentives, Amsterdam, Holland: North Holland.

Sertel M.R., 1987. Workers' Enterprises are not Perverse. European Economic Review. 31: 1619-1625.

Tobin J., 1986. Inflation and Unemployment in the Share Economy. Journal of Comparative Economics, 10: $460-463$. Vanek J., 1970. The General theory of Labor-Managed Market Economies. Ithaca, NY: Cornell University Press.

Wadhwani S., 1987. The macroeconomic Implications of Profit-Sharing. Some Empirical Evidence. Economic Journal, Supplement, 97: 171-183.

Ward B.N., 1958. The Firm in Illyria; Market Syndicalism. The American Economic Review, 48: 566-589.

Weitzman M.L., 1974. Prices vs. Quantities. Review of Economic Studies, 41: 477-491.

Weitzman M.L., 1982. Increasing Returns and the Foundations of Unemployment Theory. Economic Journal, $92: 787$ 804.

Weitzman M.L., 1983. Some Macroeconomic Implications of Alternative Compensation Systems. Economic Journal, 93: 763-783.

Weitzman M.L., 1984. The Share Economy. Cambridge, MA: Harvard University Press.

Weitzman M.L., 1985a. Profit Sharing as Macroeconomic Policy. The American Economic Review, 75: 41-45.

Weitzman M.L., 1985b. The Simple Macroeconomics of Profit Sharing. The American Economic Review, 75: $937-953$.

Weitzman M.L., 1987. Steady State Unemployment under Profit Sharing. The Economic Journal, 97: 96-105.

Zanella G., 2001. Partecipazione con avversione al rischio e coordination failures: riconsiderazione e tentativo di sintesi dei modelli di Weitzman e Meade. Rivista di Politica Economica, 91: 119-156.

\section{Appendix}

Flow diagram of Meade's proposal.

The risk of volatility in the income of workers is offset by the social dividend and the spread of wealth among citizens (see dark blue box).

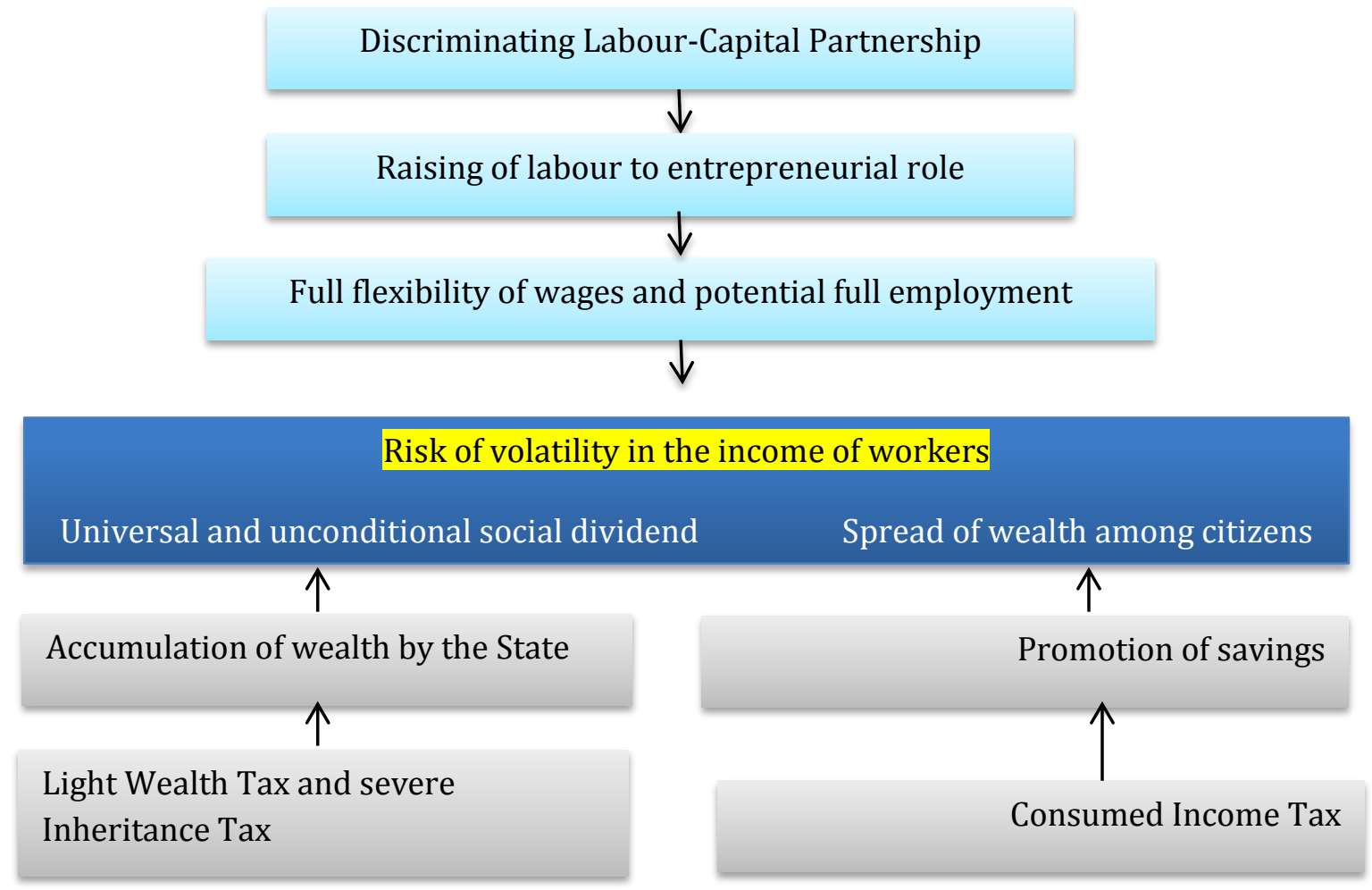

